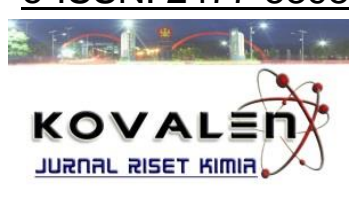

\title{
PENENTUAN SUHU DAN pH HIDROLISIS KITOSAN DARI CANGKANG KEONG SAWAH (Pila ampullacea) TERHADAP BERAT MOLEKUL HIDROLISATNYA
}

\section{[Determination of Chitosan Hydrolysis Temperature and pH from Rice Field Snail Shell (Pila ampullacea) to the Molecular Weight of the Hydrolyzate]}

\author{
Nurhaeni $^{1}$, Angriani Sambali ${ }^{1}$, Pasjan Satrimafitrah ${ }^{1}$, Jusman ${ }^{1}$ \\ 1) Jurusan Kimia, Fakultas MIPA, Universitas Tadulako, Palu \\ J. Soekarno Hatta Km.9, Kampus Bumi Tadulako Tondo Palu, Telp. 0451- 422611
}

*)Coresponding author: angrianisambali09@gmail.com(082292129005)

Diterima 13 Desember 2018, Disetujui 27 Februari 2019

\begin{abstract}
Research has been carried out on determining the temperature and $\mathrm{pH}$ of hydrolysis of chitosan from rice field snail shell (Pila ampullacea) to the molecular weight of the hydrolyzate using the a-amylase enzyme. This study aims to determine the best hydrolysis temperature and $\mathrm{pH}$ that can produce chitosan hydrolyzates with low molecular weight. Temperature variations used to hydrolyze chitosan from rice field snail shell include $30{ }^{\circ} \mathrm{C}, 40 \stackrel{\circ}{\circ} \mathrm{C}, 50 \stackrel{\circ}{\circ} \mathrm{C}, 60{ }^{\circ} \mathrm{C}$ and $70{ }^{\circ} \mathrm{C}$. Whereas the hydrolysis $\mathrm{pH}$ applied to hydrolyze chitosan were $4.5 ; 5.0 ; 5.5 ; 6.0$ and 6.5. Measurement of chitosan hydrolyzate molecular weight was carried out by applying the Mark-Houwink method and the observed parameter was the molecular weight of chitosan hydrolyzate. The results showed that the chitosan hydrolysis temperature was $50 \stackrel{\circ}{\circ}$ and were able to reduce molecular weight to $14.488 \mathrm{~g} / \mathrm{mol}$. Whereas the most effective hydrolysis $\mathrm{pH}$ was $\mathrm{pH} 5.5$ which decreased the molecular weight to $12.850 \mathrm{~g} / \mathrm{mol}$.
\end{abstract}

Keywords: Chitosan hydrolysate, rice field snail shell, $\alpha$-amylase enzyme.

\begin{abstract}
ABSTRAK
Telah dilakukan penelitian tentang penentuan suhu dan $\mathrm{pH}$ hidrolisis kitosan dari cangkang keong sawah (Pila ampullacea) terhadap berat molekul hidrolisatnya dengan menggunakan enzim $\alpha-$ amilase. Penelitian ini bertujuan untuk menentukan suhu dan $\mathrm{pH}$ hidrolisis terbaik yang dapat menghasilkan hidrolisat kitosan dengan berat molekul yang rendah. Variasi suhu yang digunakan untuk menghidroisis kitosan dari keong sawah antara lain $30^{\circ} \mathrm{C}, 40^{\circ} \mathrm{C}, 50^{\circ} \mathrm{C}, 60^{\circ} \mathrm{C}$ dan $70^{\circ} \mathrm{C}$. Sedangkan $\mathrm{pH}$ hidrolisis yang diterapkan untuk menghidrolisis kitosan dari cangkang keong sawah antara lain 4,5;5,0;5,5;6,0 dan 6,5. Pengujian berat molekul hidrolisat kitosan dilakukan dengan menerapkan metode Mark-Houwink dan parameter yang diamati adalah berat molekul hidrolisat kitosan. Hasil penelitian menunjukan bahwa suhu optimum hidrolisis kitosan yaitu suhu $50^{\circ} \mathrm{C}$ dan menurunkan berat molekul menjadi $14.488 \mathrm{~g} / \mathrm{mol}$. Sedangkan untuk $\mathrm{pH}$ optimum hidrolisis adalah $\mathrm{pH}$ 5,5 dan menurunkan berat molekul $12.850 \mathrm{~g} / \mathrm{mol}$.
\end{abstract}

Kata Kunci : hidrolisat kitosan, cangkang keong sawah, enzim a-amilase 


\section{LATAR BELAKANG}

Keong sawah (Pila ampullacea) merupakan siput air tawar yang mudah dijumpai di sawah dan danau. Keong sawah memiliki warna cangkang hijau hingga hitam dengan bentuk yang mirip dengan siput murbai (keong mas). Keong sawah mengandung protein yang cukup tinggi, tetapi pemanfaatan keong sawah masih sebatas konsumsi oleh masyarakat. Di Indonesia, khususnya di daerah Sulawesi Tengah, keong sawah banyak ditemukan di sawah yang pada umumnya menjadi hama karena memakan batang padi yang baru ditanam sehingga mengganggu pertumbuhan padi. Selain menjadi hama, keong sawah juga belum dimanfaatkan secara maksimal.

Pemanfaatan keong terbatas pada konsumsi daging keong oleh sebagian masyarakat yang menyebabkan cangkangnya sangat melimpah dan mudah ditemukan. Hingga saat ini, limbah cangkah keong sawah lebih banyak diolah sebagai pakan ternak (unggas). Nasution et al. (2013) melaporkan bahwa cangkang keong sawah memiliki kandungan senyawa kitin yang selanjutnya dapat ditransformasi menjadi kitosan. Hasil penelitian Hendrawan (2011), menyatakan bahwa kitosan cangkang keong bakau (Telescopiumsp) sekitar 8,5\%.

Kitosan merupakan biopolymer yang memiliki sumber kitin yang melimpah di Indonesia. Kitosan banyak dimanfaatkan dalam berbagai bidang contohnya pangan dan medis. Kitosan memiliki berat molekul cukup besar hingga mencapai $4 \times 10^{40}$ $\mathrm{g} / \mathrm{mol}$, dengan berat molekul yang besar ini membuat kitosan terkendala dalam pengaplikasiannya. Diperlukan metode hidrolisis untuk menurunkan berat molekul kitosan. Metode untuk menurunkan berat molekul meliputi: depolimerisasi dengan hidrolisis asam atau oksidatif - reduktif menggunakan $\mathrm{O}_{3}, \mathrm{NaNO}_{2}$ atau $\mathrm{H}_{2} \mathrm{O}_{2}$ sedangkan depolimerisasi fisik dengan menggunakan ultrasonik dan membutuhkan peralatan yang khusus dan ukuran berat molekul yang dihasilkan tidak bisa dikontrol (Lin et al.., 2003). Hidrolisis kimia memiliki banyak kelemahan, diantaranya menggunakan larutan kimia dengan konsentrasi tinggi yang residunya akan mencemari lingkungan, membutuhkan reaktor yang kompleks, yield yang rendah, ukuran berat molekulnya sulit dikontrol (Tsao et al.., 2011). Metode enzimatis menawarkan keuntungan seperti kondisi operasi ringan, reaksi mudah dikontrol, spesifisitas tinggi, yield tinggi serta ramah lingkungan (Roncal et al., 2007).

Senyawa kitosan memiliki kelarutan yang cukup tinggi pada beberapa asam organik, tetapi tidak larut dalam air dan pelarut alkali, sehingga pada berat molekul yang tinggi, kitosan lebih sulit terserap secara in vivo. Oleh sebab itu, perlu dilakukan upaya untuk meningkatkan kelarutan kitosan. Kelarutan kitosan dapat ditingkatkan dengan cara menurunkan berat molekulnya. Salah satu cara menurunkan berat molekul kitosan adalah 
dengan cara hidrolisis baik menggunakan asam maupun enzim. Metode ensimatik adalah langkah yang paling menguntungkan untuk dilakukan karena reaksinya ringan (mild) dan spesifikasi tinggi serta hasil hidrolisis dengan berat molekul rendah dapat diaplikasikan sebagai sistem pengantar DNA (Li et al., 2005). Hasil hidrolisis kitosan disebut hidrolisat kitosan (Jeon dan Kim., 2000).

Hidrolisis kitosan secara enzimatik dapat menggunakan enzim spesifik (kitosanase), namun hingga saat ini ketersediaan enzim tersebut di pasaran masih sulit ditemukan dan harganya cukup mahal. Kemudian muncul penelitianpenelitian dengan enzim lain diantaranya enzim selulase (Lin, 2003), enzim pektinase (Kittu et al, 2003), enzim pepsin (Roncal et al, 2007), enzim protease (Li et al, 2005), dan enzim lipase (Lee et al, 2008). Enzim yang sering dijumpai di pasar Indonesia dan dipakai di Industri adalah enzim $\alpha$-amilase.

Handayani et al. (2013), melaporkan bahwa enzim a-Amilase (perbandingan enzim : substrat terbaik 0,025\%) dapat digunakan untuk menghidrolisis kitosan komersial dengan waktu hidrolisis 2 jam dan mampu menurunkan berat molekul dari 1680-1750 kDa menjadi 144,18 kDa. Sedangkan hasil penelitian Rokhati et al. (2015), melaporkan bahwa hidrolisis kitosan menggunakan kombinasi enzim endo-glucanase dan cellobiohydrolase dengan waktu hidrolisis 1 jam dapat menurunkan berat molekul dari $1280 \mathrm{kDa}$ menjadi $435 \mathrm{kDa}$.

Hingga saat ini, belum ditemukan publikasi mengenai hidrolisis kitosan menggunakan enzim a-amilase (E-2248). Dengan pertimbangan demikian, maka peneliti memilih melakukan penelitian tentang hidrolisis kitosan dari cangkang keong sawah (Pila Ampullacea) untuk menurunkan berat molekul dengan menggunakan enzim $\alpha$-amilase (E-2248).

\section{METODE PENELITIAN}

\section{Bahan dan Peralatan}

Bahan dasar yang digunakan dalam penelitian ini adalah kitosan cangkang keong sawah diperoleh dari isolasi kitin yang dilakukan oleh Toman (2018), bahan pembantu yang terdiri dari enzim $\alpha$ amilase, $\mathrm{CH}_{3} \mathrm{COOH}, \mathrm{NaOH} 10 \mathrm{~N}$ dan aquadest.

Peralatan yang digunakan dalam penelitian ini mencangkup neraca analitik, shaker inkubator, lemari pendingin, viscometer Ostwald, hotplate, thermometer, waterbath, statif dan klem, buret, pipet tetes dan alat-alat gelas yang umumnya digunakan dalam laboratorium kimia.

\section{Prosedur Penelitian}

\section{Pembuatan larutan kitosan pH 4,5 (Handayani et al. 2013)}

Kitosan cangkang keong sawah dengan berat molekul awal 251,432 g/mol (Toman, 2018) sebanyak $10 \mathrm{~g}$ dilarutkan ke dalam larutan buffer asetat $\mathrm{pH} 4,5$ hingga volume mencapai $1000 \mathrm{~mL}$. 


\section{Hidrolisis enzimatik kitosan (Handayani et al., 2013).}

\section{Perlakuan suhu hidrolisis kitosan}

Larutan kitosan $\mathrm{pH}$ 4,5 sebanyak $100 \mathrm{~mL}$ dimasukan ke dalam erlenmeyer $250 \mathrm{~mL}$ kemudian dilakukan penambahan enzim $\alpha$-amilase dengan konsentrasi 0,1 $\%$ b/v. Selanjutnya diinkubasi pada inkubator bergoyang selama 5 jam dengan variasi suhu $30^{\circ} \mathrm{C}, 40^{\circ} \mathrm{C}, 50^{\circ} \mathrm{C}, 60^{\circ} \mathrm{C}$ dan $70^{\circ} \mathrm{C}$. Hidrolisis dihentikan dengan mendidihkan larutan selama 15 menit. Hasil hidrolisis kemudian ditambahkan $\mathrm{NaOH} 10 \mathrm{~N}$ tetes demi tetes sampai terbentuk gel kitosan hidrolisat. Gel kemudian dicuci dengan air sampai netral dan kemudian disaring. Residu selanjutnya di oven selama 24 jam pada suhu $40{ }^{\circ} \mathrm{C}$. Kitosan hidrolisat digerus dan diayak dengan ayakan 60 mesh. Parameter yang diukur adalah berat molekul hidrolisat cangkang keong sawah. Perlakuan suhu terbaik dilanjutkan untuk perlakuan $\mathrm{pH}$ hidrolisis enzimatik. Masingmasing taraf perlakuan dilakukan sebanyak 3 kali sehingga terdapat 15 unit percobaan.

\section{Perlakuan $\mathrm{pH}$ hidrolisis kitosan}

Larutan kitosan $\mathrm{pH}$ 4,5 sebanyak $100 \mathrm{~mL}$ dimasukan ke dalam erlenmeyer $250 \mathrm{~mL}$, ditambahkan enzim $\alpha$-amilase dengan konsentrasi $0,1 \% \mathrm{~b} / \mathrm{v}$. Selanjutnya diinkubasi pada inkubator bergoyang selama 5 jam dengan suhu terbaik $50{ }^{\circ} \mathrm{C}$ pada variasi $\mathrm{pH} 4,5 ; 5,0 ; 5,5 ; 6,0$ dan 6,5. Hidrolisis dihentikan dengan mendidihkan larutan selama 15 menit.
Hasil hidrolisis kemudian ditambahkan $\mathrm{NaOH} 10 \mathrm{~N}$ tetes demi tetes pada larutan sampai terbentuk gel kitosan hidrolisat. Gel kemudian dicuci dengan air sampai netral dan kemudian disaring dan dikeringkan. Kitosan hidrolisat digerus dan diayak dengan ayakan 60 mesh. Masingmasing taraf perlakuan dilakukan sebanyak 3 kali sehingga terdapat 15 unit percobaan.

\section{Penentuan nilai berat molekul kitosan (Rokhati et al., 2015)}

Penentuan berat molekul dilakukan dengan menggunakan alat viskometer ostwald. Dipipet sebanyak $3 \mathrm{~mL}$ asam asetat lalu dimasukan kedalam Viskometer Ostwald, waktu laju alirnya dicatat. Kemudian sampel larutan kitosan hasil hidrolisis dimasukan ke dalam Viskometer Ostwald. waktu laju alir sampel diukur. Nilai viskosimeter dihitung dengan persamaan Mark-Houwink:

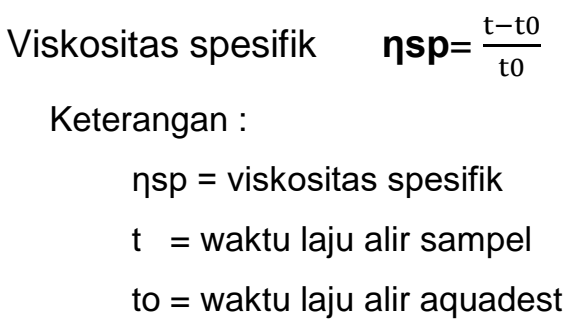

Viskositas intrinsik dapat ditentukan dengan mengukur viskositas spesifik pada beberapa konsentrasi yaitu 0,$02 ; 0,04$; 0,$06 ; 0,08$ dan $0,1 \quad$ (b/v) dan mengekstrapolasi grafik $\eta s p / c$ versus $c$ pada konsentrasi sama dengan nol.

$$
\eta \mathrm{np} / \mathrm{c}=[\eta]+\mathrm{K}^{\prime}[\eta]^{2} \mathrm{C}
$$


Setelah mengetahui viskositas intrinsik, maka berat molekul kitosan dapat dihitung menggunakan persamaan:

$$
\begin{aligned}
& \text { Bobot molekul viskositas } \eta=K[M]^{\alpha} \\
& \begin{array}{l}
\text { dimana: } \\
\eta s p=\text { Viskositas Spesifik (detik) } \\
\eta \quad=\text { Viskositas zat } \\
M \quad=\text { Berat molekul zat g/mol } \\
t \quad=\text { Waktu laju alir sampel (detik) } \\
\mathrm{t}_{0} \quad=\text { Waktu laju alir solvent (detik) } \\
\mathrm{K} \quad=3,5 \times 10^{-4} \mathrm{ml} / \mathrm{g} \\
\alpha \quad=0,76
\end{array}
\end{aligned}
$$

\section{HASIL DAN PEMBAHASAN}

\section{Hasil hidrolisis enzimatik kitosan}

Hidrolisis enzimatik kitosan dilakukan dengan dua tahap perlakuan (perlakuan suhu dan $\mathrm{pH}$ hidrolisis). Kitosan awal yang digunakan untuk pembuatan hidrolisat memiliki berat molekul sebesar $251.432 \mathrm{~g} / \mathrm{mol}$ diperoleh dari isolasi kitin yang dilakukan oleh Toman (2018). Enzim yang digunakan yaitu enzim $\alpha$-amilase (E-2248).

\section{Suhu hidrolisis enzim}

Hidrolisis kitosan cangkang keong sawah dilakukan dengan variasi suhu hidrolisis enzim $30^{\circ} \mathrm{C}, 40^{\circ} \mathrm{C}, 50^{\circ} \mathrm{C}, 60^{\circ} \mathrm{C}$ dan $70^{\circ} \mathrm{C}$. Berat molekul hidrolisat kitosan terhadap variasi suhu enzim diperoleh masing-masing secara berturut-turut yaitu 18.654; 16.291; 14.488; 14,979 dan $15.257 \mathrm{~g} / \mathrm{mol}$.

Pada Gambar 1 menunjukan pengaruh suhu hidrolisis terhadap penurunan berat molekul hidrolisat kitosan, yang semakin tinggi dengan bertambahnya suhu hidrolisis yang digunakan, maka semakin kecil berat molekul kitooligosakarida yang dihasilkan, namun pada suhu $50^{\circ} \mathrm{C}$ berat molekul kitooligosakarida yang dihasilkan mencapai titik minimum. Penurunan berat molekul kitosan setelah hidrolisis enzimatis terjadi karena adanya pemutusan ikatan pada rantai polimer kitosan menjadi lebih pendek dan berat molekul kitosan menjadi lebih rendah (Susilowati.et al.., 2015). Kitooligosakarida dengan berat molekul rendah dilaporkan memiliki banyak aktivitas biologi seperti antimikroba, antikanker, antioksidan, dan efek imunostimulan yang tergantung pada sifat fisiko-kimianya (Qin et al, 2002).

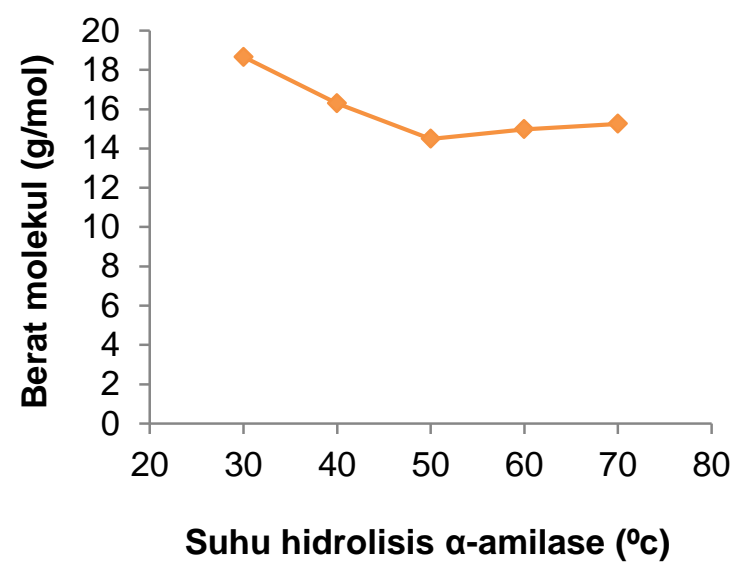

Gambar 1 Grafik hubungan berat molekul hidrolisat kitosan pada berbagai suhu

Dari hasil penelitian diperoleh suhu hidrolisis terbaik adalah $50^{\circ} \mathrm{C}$ sebesar $14.488 \mathrm{~g} / \mathrm{mol}$ yang merupakan variasi suhu yang menghasilkan berat molekul minimum, karena peranan enzim dalam mendegradasi rantai polisakarida yang memotong ikatan glikosidik pada ujung 
rantai sehingga menghasilkan penurunan berat molekul. Dari hasil penelitian Lee et al (2008), dengan menggunakan enzim lipase dengan suhu hidrolisis $55^{\circ} \mathrm{C}$ diperoleh rendemen kitooligomer sebesar 94\%. Sementara itu, Kumar dan Tharanathan (2004), menyatakan bahwa penggunaan protease pada hidrolisis kitosan pada suhu $45^{\circ} \mathrm{C}$ selama 1-5 jam mampu menghasilkan berat molekul hidrolisat kitosan 5-10 kDa dengan rendemen 78 - 84\%. Penigkatan suhu dapat meningkatkan kecepatan reaksi arena molekul atom mempunyai energi yang lebih besar dan mempunyai kecenderungan untuk berpindah (Lee, 1992). Menurut Holum (1968) menyatakan bahwa peningkatan suhu reaksi sebesar $10^{\circ} \mathrm{C}$ akan meningkatkan aktivitas enzim 50-100\%. Penggunaan suhu lebih dari $70^{\circ} \mathrm{C}$ mengakibatkan aktivitas enzim $\alpha-$ amilase menurun, karena terjadi denaturasi protein enzim sehingga menjadi inaktif. Ketika reaksi di jalankan pada titik didih maka semua enzim akan rusak (Tranggono dan Setiadji, 1989).

Peranan enzim dalam mendegradasi rantai polisakarida dapat dibedakan berdasarkan cara enzim tersebut mendepolimerisasi rantai polisakarida dengan memotong ikatan glikosidik. Tipe pertama bersifat endo-aksi dengan memotong ikatan glikosidik secara acak. Akibatnya polisakarida terurai menjadi bentuk yang lebih kecil dengan ukuran acak. Pada tipe ini berat molekul dari polimer turun secara cepat. Sedangkan tipe kedua adalah ekso-aksi yang lebih suka memotong ikatan glikosidik pada ujung rantai sehingga menghasilkan bentuk monomer. Umumnya berat molekul polimer kitosan turun secara konstan dan lambat pada tipe ekso-aksi ( $\mathrm{Li}$ et al dalam Nazaruddin, M, 2010). Berdasarkan kedua tipe tersebut dalam mendegradasi polimer, enzim a-amilase dapat digolongkan dalam tipe endo-aksi. Hal tersebut dapat dilihat dari pola penurunan nilai berat molekul yang secara signifikan.

Berdasarkan hasil analisis statistik menunjukan bahwa perlakuan suhu hidrolisis berpengaruh sangat nyata terhadap penurunan berat molekul hidrolisat kitosan. Hasil analisis lanjut dengan uji Duncan $(\alpha=0,05)$ menunjukan bahwa suhu berat molekul hidrolisat berpengaruh nyata pada suhu hidrolisis $30^{\circ} \mathrm{C}, 40^{\circ} \mathrm{C}, 50^{\circ} \mathrm{C}, 60^{\circ} \mathrm{C}$ dan $70^{\circ} \mathrm{C}$. Sehingga dapat disimpulkan bahwa berat molekul menurun secara signifikan pada suhu hidrolisis.

\section{pH hidrolisis}

Hidrolisis kitosan cangkang keong sawah dilakukan dengan variasi $\mathrm{pH}$ hidrolisis enzim 4,5; 5,0; 5,5; 6,0 dan 6,5. Berat molekul kitosan hidrolisat terhadap variasi suhu enzim diperoleh masingmasing secara berturut-turut yaitu 16.776; 14.919; $12.850 ; 12.867$ dan $13.014 \mathrm{~g} / \mathrm{mol}$.

Pada Gambar 2 menunjukan pengaruh $\mathrm{pH}$ hidrolisis terhadap penurunan berat molekul kitooligosakarida, yang dimana semakin 
tinggi $\mathrm{pH}$ hidrolisis hidrolisat yang digunakan maka semakin kecil berat molekul.

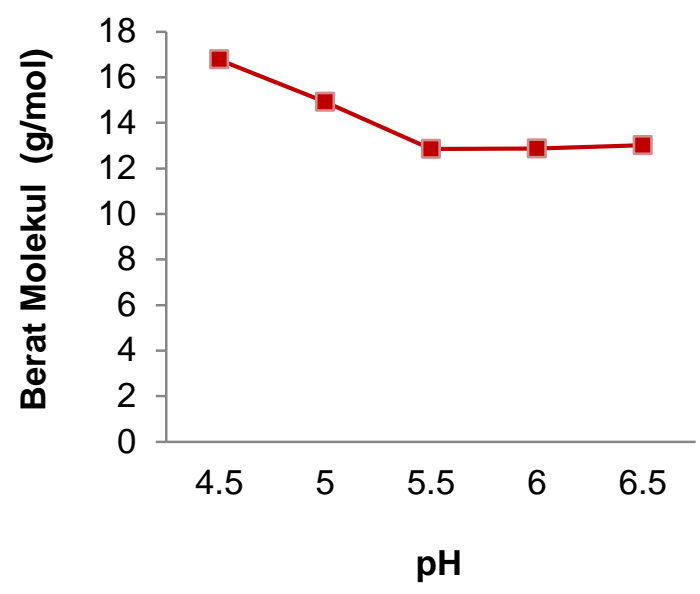

Gambar 2 Grafik hubungan berat molekul hidrolisat kitosan pada berbagai $\mathrm{pH}$ hidrolisis

Dari hasil penelitian diperoleh $\mathrm{pH}$ hidrolisis terbaik adalah 5,5 sebesar $12.850 \mathrm{~g} / \mathrm{mol}$, yang merupakan variasi $\mathrm{pH}$ yang menghasilkan berat molekul minimum karena kitosan terlarut dengan baik dan enzim $\alpha$-amilase bekerja secara optimal, dimana semakin banyak pemutusan rantai polimer menjadi molekul yang sederhana. Hal tersebut ditandai dengan meningkatnya viskositas kelarutan dari hidrolisat kitosan tersebut. Sehingga pada penelitian ini hidrolisis $\mathrm{pH}$ optimum terjadi pada $\mathrm{pH}$ 5,5 karena pada variasi $\mathrm{pH}$ selanjutnya menghasilkan berat molekul yang konstan.

Shengjun Wu (2011) melaporkan bahwa enzim $\alpha$-amilase jenis mesofilik memiliki $\mathrm{pH}$ optimum 5. Pada penelitian Handayani et al. (2013), menyatakan bahwa hidrolisis enzimatis menggunakan a-amilase termofilik pada $\mathrm{pH} 5$ mampu menurunkan berat molekul dari 1.6801.750 kDa menjadi 144,18 kDa. Dan pada hasil penelitian Rokhati Et al. (2015), menyatakan bahwa hidrolisis menggunakan enzom endo-glucanase pada $\mathrm{pH} 5$ mengakibatkan penurunan berat molekul yang besar yaitu dari 1.280 kDa menjadi 392 kDa. Menurut Taylor (2004) apabila enzim $\alpha$-amilase digunakan $\mathrm{pH}$ yang terlalu asam (protonasi) maka aktivitas enzim akan berkurang, sedangkan pada $\mathrm{pH}$ basa terjadi deprotonasi sehingga aktivitasnya cenderung menurun.

Menurut Lee et al dalam Nazaruddin, M (2010), enzim non-spesifik dapat mengkatalis dua reaksi yang berbeda karena memiliki dua sisi aktif pada molekul enzim atau satu sisi aktif yang dwifungsional. Pada kitosan jumlah dari gugus $\mathrm{N}$-asetil, sebaran gugus $\mathrm{N}$-asetil dalam rantai linear, serta berat molekul atau sebaran rantai panjangnya akan mempengaruhi kemampuan enzim tersebut dalam mendegradasi kitosan.

Aktivitas suatu enzim dapat mencapai optimum pda $\mathrm{pH}$ lingkungan yang sesuai. Saat $\mathrm{pH}$ enzim tidak berada pada $\mathrm{pH}$ optimumnya, maka aktivitas enzim akan menurun akibat perubahan ionisasi enzim, substrat, atau kompleks enzim dengan substrat, sehingga. Beberapa jenis enzim yang dapat menghdirolisis kitin memiliki aktivitas optimum pada kisaran $\mathrm{pH}$ asam hingga netral. Akan tetapi, pada $\mathrm{pH}$ netral, kitosan berberat molekul tinggi lebih sulit larut 
dalam air (llyina et al., 1999). Umumnya kitosan pada $\mathrm{pH}$ rendah dapat tersuspensi hingga terlarut pada pelarut asam organik (Peniston, 1980), sehingga semakin tinggi keaasaman pelarut akan meningkatkan kelarutan kitosan. Suhartono (1989) menyatakan bawah $\alpha$-amilase umumnya stabil pada $\mathrm{pH} 5,5$ - 8,0 dan aktivitas optimum pada $\mathrm{pH} 4,8$ - 6,5. Pada penelitian yang dilakukan $\mathrm{pH}$ hidrolisis terbaik diperoleh pada $\mathrm{pH} 5,5$.

Mekanisme kerja $\alpha$-amilase dalam menghdirolisis kitosan dapat diduga sama dengan mekanisme hidrolisis amilosa. Enzim a-amilase menghidrolsis amilosa melaluii dua tahap, yaitu degradasi menjadi dekstrin yang terjadi secara acak yang berlangsung sangat cepat diikuti dengan menurunnya viskositas dengan cepat., sehingga amilosa terurai menjadi bentuk yang lebih kecil dengan ukuran acak. Pada tahap kedua relatif sangat lambat dengan pembentukan glukosa dan maltosa sebagai hasil akhir (Hom dan Eijsink, 2003). Pembentukan gula reduksi menunjukan aktifitas enzim yang memotong ikatan glikosida pada kitosan. Semakin tinggi aktivitas enzim maka semakin tinggi pula gula reduksi yang dihasilkan. Penentuan kadar gula reduksi dapat digunakan untuk mengetahui peningkatan jumlah rantai kitosan yang terputus dari waktu ke waktu. Oleh karena itu semakin rendah berat molekul kitosan maka semakin tinggi kadar gula reduksi.
Berdasarkan hasil analisis statistik menunjukan bahwa perlakuan $\mathrm{pH}$ hidrolisis berpengaruh sangat nyata terhadap penurunan berat molekul hidrolisat kitosan. Hasil analisis lanjut dengan uj Duncan $(\alpha=0,05)$ menunjukan bahwa suhu berat molekul hidrolisat berpengaruh nyata pada $\mathrm{pH}$ hidrolisis 4,5; 5,$0 ; 5,5 ; 6,0$ dan 6,5 . Sehingga dapat disimpulkan bahwa berat molekul menurun secara signifikan pada $\mathrm{pH}$ hidrolisis.

\section{KESIMPULAN}

Suhu hidrolisis kitosan terbaik adalah $50^{\circ} \mathrm{C}$ dengan berat molekul yang didapatkan sebesar 14,488 $\mathrm{g} / \mathrm{mol}$ sedangkan $\mathrm{pH}$ hidrolisis terbaik adalah 5,5 dengan jumlah penurunan berat molekul $12,850 \mathrm{~g} / \mathrm{mol}$

\section{DAFTAR PUSTAKA}

Handayani, H., Siwi, P., Rokhati, N. 2013. Depolimerisasi kitosan dengan hidrolisa enzimatik menggunakan enzim a-Amilase. Jurnal Teknologi Kimia dan Industri 2(4): 55-64.

Hendrawan \& Rachmawani, D. 2011. Studi kandungan kitosan pada keong (Telescopium sp) di kawasan konservasi mangrove kelurahan pamusian kota tarakan. Jurnal Harpodon Borneo 4(2).

Holum, J. R dan Brendy, J.E. 1968. Chemistry. New York: Jhon Wiley dan Son. pp.681.702

Hom, S.J. and Eijsink, V.G.H. 2003. A reliable reducing sugar end assay for chito- oligosaccharides, Carbohydrate Polymers, 56: 35-39. 
Ilyina, A V., Tatarinova, N Y., Varlamov, V P. 1999. The Preparation of Lowmolecular weight Chitosan Using chitinolytic Complex from Streptomyces kurssanovii. Process Biochemistry 34(9): 875-878.

Jeon YJ, Kim SK. 2000. Production of chitooligosaccharides using an ultrafiltration membrane reactor and their antibacterial activity. $J$ Carbohydrate Polymer 41:133141.

Kumar, A.B.V., Varadaraj, M.C., Gowda, L.R., and Tharanathan, R.N., 2004. Low molecular weight chitosanspreparation with the aid of pronase, characterization and their bactericidal activity towards Bacillus cereus and Escherichia coli, Biochimica et Biophysica Acta, 1770: 495-505.

Lee DX, Xia WS, Zhang JL. 2008. Enzymatic preparation of chitooligosaccharides by commercial lipase. Food chem. 111:291-295

Lee, M. Nah, Kwn Y, Koh JJ, Ko KS, Kim SW. 1992. Purification and Charateristic of Chitonase from Bacillus sp. HW-002 Journal of Microbiology and Biotechnology 6: 19-25.

Li J, Du Y, Yang J, Feng T, Li A, Chen P. 2005. Preparation and characterisation of low molecular weight chitosan and chito-oligomers by a commercial enzyme. Polym Degradation and Stability 87: 441448.

Lin, Q. and Ma, K.L. 2003. Study of Catalytic Hydrolysis of Chitosan by Cellulase, China Surfactant Detergent and Cosmetics 33: 22-25.

Nasution, P., Sumiati, S., Wardhana, I W. 2013. Studi penurunan TSS, Turbidity dan COD dengan menggunakan kitosan dari limbah cangkang keong sawah (Pila ampullaceal) sebagai biokoagulan dalam pengolahan limbah cair PT. Sido muncul TBK Semarang. Jurnal Teknik Lingkungan 4(1): 110.

Peniston, Q. P \& Jhonson, E. 1980. Process of the manufacture of chitosan. US patent

Qin, C. Du, Y.M dan Xiao, L. 2002. Effect of Hydrogen Peroxide Treatment on the Molecular Weight and Structure of Chitosan. Polym Degradation And Stability 76:211-218.

Rokhati, N., A. Prasetyaningrum, D. Ikhsan dan T. D. Kusworo. 2015. Peningkatan Mutu Simpan Buah dengan Coating Film Komposit Tapioka-Kitosan. Prosiding Seminar Nasional Teknik Kimia "Kejuangan Pengembangan Teknologi Kimia untuk Pengolahan Sumber Daya Alam Indonesia, 18 Maret 2015. Yogyakarta, hal. 1-7.

Roncal, T., Oviedo, A., Armentia, I.I.D., Fernandez, L., Villarian, M. 2007. High Yield Production Of MonomerFree Chitosan Oligosaccharides By Pepsin Catalyzed Hydrolysis Of A High Deacetylation Degree Chitosan. Carbohydrate Research 342(18): 2750-2756.

Suhartono, M.T. 1989. Enzim dan Bioteknologi. Bogor: PAU IPB.

Taylor. 2004. Electrospinning of chitosan solution in acetic acid with poly(ethylene oxide). Journal of Biomaterials Science 15(6).

Tranggono dan Sutardi. 1989. Biokimia dan Teknologi Pasca Panen. Yogyakarta: Pusat Antar Universitas Pangan Dan Gizi, Gadjah Mada University Press, 142 hal 
Tsao, C.T., Chang, C.H., Lin, Y.Y., Wu, M.F.,Han, J.L., and Hsieh, K.H. 2011. Kinetic study of acid depolymerization of chitosan and effects of low molecular weight chitosan on erythrocyte rouleaux formation. Carbohydrate Research, 346(1): 94-102. 